\title{
Molecular analysis of the promoter region of the Clostridium difficile toxin B gene that is functional in Escherichia coli
}

\author{
K.-P. SONG and C. FAUST \\ Department of Cell Biology and Biochemistry, Texas Tech University Health Sciences Center, 36014 th Street, \\ Lubbock, TX 79430, USA
}

\begin{abstract}
Clostridium difficile is a human pathogen that produces two types of toxins, $\mathbf{A}$ and $\mathbf{B}$, that cause a potentially lethal gastrointestinal syndrome termed pseudomembranous colitis. Virtually nothing is known about the mechanism of regulation of toxin production in this organism, and cis-regulatory regions of neither toxin have yet been identified, thus prompting this investigation. A motif homologous with the ShineDalgarno sequence of Escherichia coli occurs upstream from the putative initiation codon of toxin B, making this region also a candidate to contain a promoter. Therefore, a subgenomic DNA library of $C$. difficile in a plasmid vector was first constructed encompassing the 5 '-end of the toxin B gene. A 450-bp DNA fragment was excised from the subgenomic DNA library clone and subcloned into a promoter-probe plasmid vector that contains two divergently oriented, promoterless genes to assay for promoter function. This subcloned DNA fragment directed the expression of alkaline phosphatase, a reporter gene product of the promoterless vector, thus indicating the presence of a functional promoter. To locate the promoter more precisely, a series of nested deletions of the toxin B promoter subclone was constructed with exonuclease III. The promoter that facilitates expression of the toxin B gene in $E$. coli was localised, based on alkaline phosphatase activity. The transcriptional initiation site of toxin B mRNA in $E$. coli was mapped by primer extension analysis, suggesting two closely associated tandem start sites directed by two similarly spaced promoters within this localised region.
\end{abstract}

\section{Introduction}

Clostridium difficile is a gram-positive, spore-forming, anaerobic bacillus. It is the aetiological agent of pseudomembranous colitis (PMC) in man, a severe, potentially lethal gastrointestinal disease that is characterised by a range of clinical presentation from a self-limited diarrhoea to an acute and fulminant colitis [1-3]. The development of the disease is a serious side-effect of treatment of patients with various antimicrobial agents. It is thought that $C$. difficile causes disease by producing two exotoxins, designated toxins $\mathrm{A}$ and $\mathrm{B}$ [4-7]. Toxin $\mathrm{A}$ is a potent enterotoxin that produces extensive tissue damage in the gut mucosa of tested animals. In addition to its enterotoxic activity, toxin $\mathrm{A}$ is also cytotoxic. Toxin $\mathrm{B}$ is a potent

Received 18 March 1997; revised version accepted 24 July 1997.

Corresponding author: Professor C. Faust. Present address: Department of Microbiology, National University of Singapore, 10 Kent Ridge Crescent, Sinapore 119260 cytotoxin, although it does not cause a significant response when given intragastrically to hamsters. However, it becomes lethal in combination with low doses of toxin $\mathrm{A}$. This suggests that toxin $\mathrm{A}$ initiates tissue damage that provides toxin $\mathrm{B}$ with access to sensitive tissues. Both toxins are very high mol. wt proteins, and both appear to be produced in most toxigenic strains of $C$. difficile.

C. difficile strains can vary significantly in how much of both toxins they produce, but a $1: 1$ ratio is maintained by most strains, suggesting co-ordinated regulation [8, 9]. Although the genes for both toxins have been cloned and sequenced [10-12], thus far, the underlying molecular mechanism(s) that yield a balanced expression of both $C$. difficile toxin genes have not been elucidated. This is principally due to the inability to transform $C$. difficile. However, previous experiments by Dailey and Schloemer [13] and Barroso et al. [10] suggest that Escherichia coli may be a useful alternative organism to test for promoter activity of $C$. difficile genes. 
A candidate promoter for the toxin B gene is located between the presumed initiation codon of toxin $\mathrm{B}$ and the upstream $X b a I$ site. DNA sequence analysis of this upstream region reveals a potential ShineDalgarno ribosome-binding site, AGGAG, 8-bp 5' to the putative initiation codon of toxin B gene. It is highly homologous to both the consensus sequence of $E$. coli, as well as those of clostridial strains, as summarised by Young et al. [14]. This prompted the current study on the identification and characterisation of a promoter for toxin B. The study showed that this DNA sequence has promoter activity in $E$. coli. The transcriptional start site of toxin B mRNA was also characterised, suggesting a location for the promoter site.

\section{Materials and methods}

\section{Bacterial strains, media and plasmids}

A highly toxigenic strain of $C$. difficile (strain VPI 10463) was obtained from Virginia Polytechnic Institute and State University in Blacksburg, VA, USA. The strain was grown anaerobically in Brain-Heart Infusion Broth (Difco Laboratories, Detroit, MI, USA). The E. coli strains used were DH5 $\alpha$ F'IQ ( $\phi 80$ dlacZ $\Delta \mathrm{M} 15, \Delta$ (lacZYA-argF)U169, recA1, endA1, hsdR17 $\left(\mathrm{r}_{\mathrm{K}^{-}}, \mathrm{m}_{\mathrm{K}^{+}}\right)$, supE44, $\lambda^{-}$, thi-1, gyrA, relA1, $\left[\mathrm{F}^{\prime}\right.$, proAB${ }^{+}$, laclqZ $\left.\left.\Delta \mathrm{M} 15, \mathrm{zzf}: \mathrm{Tn} 5\left(\mathrm{Km}^{\mathrm{r}}\right]\right]\right)$ and $\mathrm{CC} 118$ (araD139, $\Delta$ (ara, leu)7697, $\Delta \operatorname{lacX} 74$, phoA $\Delta 20$, galE, galK, thi, rpsE, rpoB, argE(am), recA1). SOB medium $(500 \mathrm{ml}$ of water with tryptone $10 \mathrm{~g}$, yeast extract $2.5 \mathrm{~g}$ $\mathrm{NaCl} 0.292 \mathrm{~g}$ and $\mathrm{KCl} 0.093 \mathrm{~g}$ ) and WB buffer (glycerol $10 \%$ and distilled water $90 \%$ ) were used for the electroporation procedure. The pQF110 plasmid vector, which contains a pair of divergently oriented, promoterless reporter genes (the alkaline phosphatase gene, phoA, and the luciferase gene, lux, one on each side of the multiple cloning region), was obtained from Dr Kropinsky [15] and was used as a promoter-probe vector. The plasmid pIBI25 (International Biotechnologies, New Haven, CT, USA) was used both in the construction of the subgenomic DNA library and as a cloning vehicle.

\section{Molecular cloning, enzymes and DNA manipulations}

The E. coli strain, DH5 $\alpha \mathrm{F}^{\prime} \mathrm{IQ}$, was used in the construction of a subgenomic DNA library, and $\mathrm{CC} 118$ was used in the alkaline phosphatase assay. Both were transformed with plasmid DNA and grown aerobically on LB agar plates or in LB broth [16] supplemented with ampicillin $40 \mathrm{mg} / \mathrm{L}$ when appropriate. Isolation of plasmid DNA from $E$. coli was performed by a modified boiling lysis method [17]. Bacterial genomic DNA was obtained from $C$. difficile grown to log phase. Restriction endonucleases, T4 polynucleotide kinase, T4 DNA ligase and Klenow fragments were purchased from Boehringer Mannheim
(Indianapolis, IN, USA), New England BioLabs (Beverly, MA, USA) and Promega Corporation (Madison, WI, USA) and they were used in accordance with the manufacturers' directions. 5-Bromo-4-chloro-3-indolyl phosphate (X-P) was from United States Biochemical (Cleveland, OH, USA). The exonuclease III assay was done with the Erase-a-Base System (Promega Corporation). SuperScript ${ }^{\mathrm{TM}}$ RNAase $\mathrm{H}^{-}$ reverse transcriptase (BRL Life Technologies, Gaithersburg, MD, USA) was used in the primer extension assay. Unless otherwise stated, molecular techniques were used as described earlier [18].

\section{Synthetic oligonucleotides}

Synthetic oligonucleotides used for Southern blotting, DNA sequencing and primer extension analysis were either synthesised on a BioSearch 8700 DNA synthesiser (MilliGen/BioSearch, San Rafael, CA, USA) by the phosphoramidate method and purified by preparative polyacrylamide gel electrophoresis, or purchased from Integrated DNA Technologies (Coralville, IA, USA). The oligonucleotide primers used were as follows: (i) TOXB, 5' -TGAGTTTAGTTAATAGAAAA-3', (ii) Pri Ext, 5'-GGGACGAAATCTTACATT-3', and (iii) SEQ, 5'-GGATAAAAGTGCGCGTG-3'. Oligonucleotides were end-labelled with $\mathrm{T} 4$ polynucleotide kinase and $\left[\gamma_{-}{ }^{32} \mathrm{P}\right]$-dATP $(3000 \mathrm{Ci} / \mathrm{mmol}) \quad(\mathrm{New}$ England Nuclear, Boston, MA, USA).

\section{Electroporation}

The electroporation of $E$. coli cells was done with the Cell-Porator $^{\mathrm{TM}}$ Electroporation System and CellPorator $^{\mathrm{TM}}$ Voltage Booster from BRL Life Technologies, according to their recommendations. The electrocompetent cells were prepared by growing $500 \mathrm{ml}$ of cells in SOB medium with vigorous aeration at $37^{\circ} \mathrm{C}$ until an $\mathrm{OD}_{550}$ of 0.8 was reached. The cells were then washed and resuspended in $500 \mathrm{ml}$ of ice-cold sterile WB buffer twice. The cells were made competent by resuspension in $2 \mathrm{ml}$ of WB buffer. Plasmid DNA was then mixed with $20 \mu \mathrm{l}$ of electro-competent cells and suspended in the $0.15-\mathrm{cm}$ electrode gap MicroElectroporation Chamber. The electroporation procedure was carried out with the pulse setting of $330-\mu \mathrm{F}$ capacitance, $4 \mathrm{k} \Omega$ resistance and $2.4 \mathrm{kV}$ voltage, producing a time constant of $c .6 \mathrm{~ms}$.

\section{DNA sequencing}

The DNA sequence was determined by the dideoxychain termination method of Sanger et al. [19] with labelled oligonucleotide primer, SEQ. The thermal cycle sequencing reactions were performed in a Coy 50 TempCycler (Coy Laboratory Products, Grass Lake, MI, USA) with thermostable Vent $_{R}{ }^{\circledR}\left(\right.$ exo $\left.^{-}\right)$DNA polymerase (New England BioLabs). Sequencing reactions were done on denaturing polyacrylamide $5 \%$ gels [18]. 


\section{Construction of a $C$. difficile subgenomic DNA library}

The toxin B subgenomic DNA library of $C$. difficile was constructed by digesting $C$. difficile genomic DNA with EcoRV to completion. The digest containing the fragment of interest was separated by sucrose gradient centrifugation and the proper fraction identified by Southern blot analysis with an oligonucleotide probe, TOXB, which recognises the $5^{\prime}$-end of toxin $\mathrm{B}$. This fraction was cloned in a pIBI25 plasmid vector prepared by EcoRV digestion (Fig. 1) and transformed into bacterial strain $\mathrm{DH} 5 \alpha \mathrm{F}^{\prime} \mathrm{IQ}$ by electroporation. The colonies obtained were screened by the GrunsteinHogness hybridisation technique [20] with the same oligonucleotide probe.

\section{Cloning of a DNA fragment containing a putative promoter element}

Clone B (Fig. 1) was digested with RsaI, separated by agarose gel electrophoresis, and a 2.2-kb DNA fragment was electro-eluted, ligated to a Sma I-digested pIBI25 plasmid vector, and the product was transformed into $E$. coli strain $\mathrm{DH} 5 \alpha \mathrm{F}^{\prime} \mathrm{IQ}$. The resultant clone, pRStoxB (Fig. 1), was then digested with $\mathrm{Xba \textrm {I }}$ to release a fragment of $460 \mathrm{bp}$. This DNA fragment was subcloned into the $X b a \mathrm{I}$ site upstream of a promoterless alkaline phosphatase gene of $E$. coli vector $\mathrm{pQF} 110$ [15]. The resultant recombinant clone, pPB (Fig. 1), was transformed into an alkaline phosphatase-deficient bacterial host, $\mathrm{CC} 118$, and examined for alkaline phosphatase activity. The portion of the toxin B structural gene in the 460-bp insert DNA was in the same polarity as the alkaline phosphatase gene in pQF110 vector (Fig. 1). The junctional regions of the clones were confirmed by DNA sequencing.

\section{Alkaline phosphatase assays}

The alkaline phosphatase activities were assayed by both screening qualitatively for blue bacterial colonies grown overnight at $37^{\circ} \mathrm{C}$ on LB plates with X-P $40 \mu \mathrm{g} / \mathrm{ml}$, and quantitatively by measuring spectrophotometrically the rate of $p$-nitrophenyl phosphate hydrolysis at $\mathrm{OD}_{420}$ by permeabilised cells according to Manoil and Beckwith [21].

\section{Construction of nested deletions of the promoter}

The pPB promoter clone DNA was prepared by digesting with both KpnI and Bam HI enzymes and then exonuclease III at $20^{\circ} \mathrm{C}$ from $0.5 \mathrm{~min}$ to $8 \mathrm{~min}$ at 30-s intervals, followed by $\mathrm{S} 1$ digestion, Klenow treatment, ligation and transformation into $\mathrm{CC} 118$ bacterial host. The S1 nuclease digestion was done at $4^{\circ} \mathrm{C}$ and with $500 \mathrm{mM} \mathrm{NaCl}$ to more rigorously control the digestion. The progressive deletion of $\mathrm{pPB}$ clone was initiated from the Bam $\mathrm{HI}$ site towards the putative promoter region of toxin B. Colonies were selected for each time point, and the plasmid DNA was prepared for further restriction enzyme characterisation by both Bss HII and HindIII, and analysed on a high resolution agarose $1.5 \%$ gel. The authenticity of each deletion clone was verified by DNA sequencing.

\section{Isolation of RNA}

Whole-cell RNA was extracted from cultures of $E$. coli as described by Reddy and Gilman [22] with slight modifications. Briefly, a $100-\mathrm{ml}$ culture of E. coli was grown to an optical density of 0.8 at $550 \mathrm{~nm}$. The cells were then resuspended in STET lysing buffer (sucrose $8 \%$, Triton X-100 5\%, $50 \mathrm{~mm}$ EDTA, $50 \mathrm{~mm}$ Tris $\mathrm{HCl}$, $\mathrm{pH} 7.0$ ), and extensively vortex mixed in phenol/ chloroform reagent. The nucleic acid was precipitated with ethanol, and dissolved in diethyl pyrocarbonate (DEPC)-treated water. The phenol/chlorofom extraction was repeated twice and the final nucleic acid pellet was dissolved in $9 \mathrm{ml}$ of DEPC-treated water containing $4.5 \mathrm{~g}$ of $\mathrm{CsCl}$, layered over a $3-\mathrm{ml}$ cushion of $5.7 \mathrm{M}$ $\mathrm{CsCl}$, and centrifuged at $30000 \mathrm{rpm}$ for $24 \mathrm{~h}$ at $20^{\circ} \mathrm{C}$ in a Beckman SW41 rotor. The supernate was discarded after centrifugation and the RNA pellet was dissolved in DEPC-treated water, and precipitated with ethanol again. Purified RNA was dissolved in $200 \mu 1$ of DEPC-treated water, and its concentration was determined by absorbance at $260 \mathrm{~nm}$.

\section{Primer extension of $m R N A$}

Primer extension was performed on whole-cell RNA extracted as above by a modified procedure of Triezenberg [23]. The annealing of the radiolabelled primer, PriExt, to the RNA was done at $80^{\circ} \mathrm{C}$ for $3 \mathrm{~min}$, followed by cooling of the sample to $37^{\circ} \mathrm{C}$ for a further $30 \mathrm{~min}$. The primer extension reaction was performed at $42^{\circ} \mathrm{C}$ for $1 \mathrm{~h}$ without actinomycin $\mathrm{D}$, and the product was analysed on a polyacrylamide $9 \%$ gel.

\section{Results}

Identification of a promoter region in clone $p P B$

Clone B (Fig. 1) from the subgenomic DNA library contained an $8.8-\mathrm{kb} E c o$ RV-digested DNA fragment, which included $3.8 \mathrm{~kb}$ of the $5^{\prime}$-end of the toxin $\mathrm{B}$ gene that was previously sequenced [10], and another uncharacterised $5 \mathrm{~kb}$ of DNA upstream from the toxin $\mathrm{B}$ gene. The DNA of clone $\mathrm{B}$ was assayed for promoter activity with the promoterless plasmid vector, $\mathrm{pQF} 110$ [15]. The resultant recombinant clone, pPB (Fig. 1), contained $400 \mathrm{bp}$ of DNA sequence upstream from the initiation codon of toxin $\mathrm{B}$. When this clone was tested on LB plates with X-P, it displayed a blue colour phenotype. The parental plasmid, $\mathrm{pQF110, \text {produced }}$ only white colonies, indicating that the blue recombinant clones exhbited a promoter activity resulting from the cloned insert. Quantitative analysis (Table 1) of the 

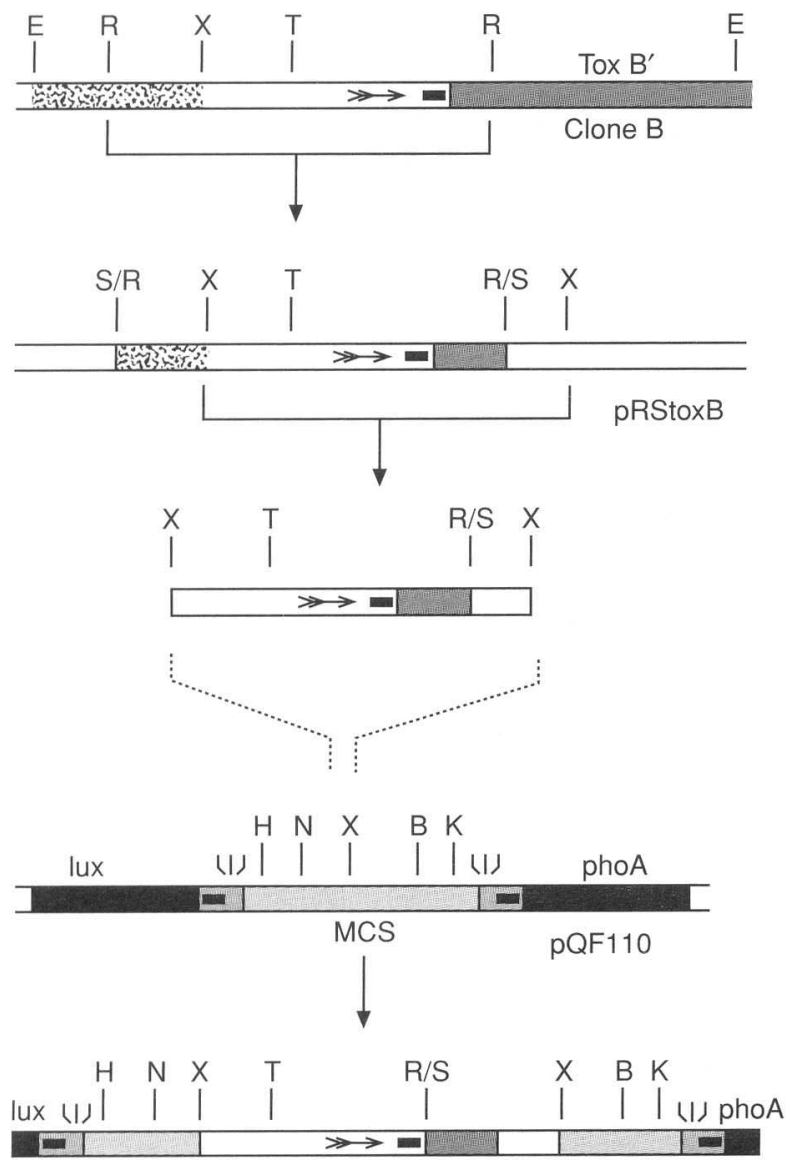

Clone pPB

Fig. 1. pPB clone construction for functional analysis. Clone pPB was constructed as described in Materials and methods. The 2.2-kb Rsa I-generated DNA fragment in clone B contains $2.15 \mathrm{~kb}$ of DNA upstream from the proposed initiation codon [10] of toxin B gene and $c$. $50 \mathrm{bp}$ of $5^{\prime}$-end toxin B structural gene. This fragment was excised and cloned into the SmaI site of pIBI25 vector, creating clone $\mathrm{pRStoxB}$. The 460 -bp $X b a \mathrm{I}$ digested DNA fragment from pRStoxB contains $398 \mathrm{bp}$ of DNA upstream from the proposed initiation codon of toxin B, $54 \mathrm{bp}$ of toxin B structural gene and $8 \mathrm{bp}$ of flanking pIBI25 vector DNA sequence. Both the reporter genes of pQF110 plasmid vector are shown as dark boxes: phoA for alkaline phosphatase and lux for luciferase. MCS is the multiple cloning site of pQF 110. $\mathrm{S} / \mathrm{R}$ and $\mathrm{R} / \mathrm{S}$ are the junctional regions created by ligating together SmaI with RsaI ends. 중 the region of the $C$. difficile DNA not previously sequenced; - , the Shine-Dalgarno sequences in the pQF110 vector and in the putative sequence for toxin $\mathrm{B}$ gene; $\gg$ the putative promoter for toxin B gene; the translational stop codons in all three reading frames present in $\mathrm{pQF} 110$ are shown, (I). Restriction endonucleases are: B, Bam HI; E, Eco RV; H, HindIII; K, KpnI; N, NcoI; RsaI; S, SmaI; T, TthIIII $\mathrm{I} ; \mathbf{X}, X b a \mathrm{I}$. This figure is not drawn to scale for simplicity of display.

promoter activity in clone $\mathrm{pPB}$ with $p$-nitrophenyl phosphate showed significant alkaline phosphatase activity compared to the parental clone, pQF110, thus confirming the earlier results from the X-P phenotypic analysis that the cloned DNA fragment indeed contained promoter activity.
Table 1. Quantitative analysis of alkaline phosphatase expression in the promoter-related clones by the $p$ nitrophenyl phosphate assay

\begin{tabular}{lcc}
\hline $\begin{array}{l}\text { Clones and deletion } \\
\text { clones }\end{array}$ & $\begin{array}{c}\text { Alkaline phosphatase } \\
\text { activity (units) }\end{array}$ & Fold increase \\
\hline CC118 & 0.1 & 0 \\
pQF110 & 0.4 & 0 \\
pPB & 66.1 & 165 \\
pPB16 & 279.6 & 699 \\
pPB17 & 607.1 & 1518 \\
pPB18 & 627.1 & 1568 \\
pPB27 & 16.1 & 40 \\
pPB71 & 6.6 & 17 \\
pPB83 & 3.9 & 10 \\
\hline
\end{tabular}

*Alkaline phosphatase activity of each clone, as measured spectrophotometrically at $\mathrm{OC}_{420}$ by the $p$-nitrophenyl phosphate assay and expressed in units as defined by Beckwith and Manoil [21].

\section{Localisation of the promoter region by nested deletion analysis}

To localise the position of the putative promoter in clone $\mathrm{pPB}$, a set of nested deletions of the clone was performed with an exonuclease III assay. Six of the clones shown (Fig. 2), represented deletions from $79 \mathrm{bp}$ to $232 \mathrm{bp}$, and they were analysed for functional promoter activity. The results of the alkaline phosphatase phenotype characterisation of these deletion clones are also shown in Fig. 2, where deletion clones pPB27, pPB71 and pPB83 conferred a white colony phenotype, and three others, pPB16, pPB17 and pPB18, conferred a blue phenotype. The alkaline phosphatase activity of the promoterless vector disappeared with a transition from deletion clone pPB18 to $\mathrm{pPB} 27$, implying that essential promoter function exists within this deleted region. A quantitative assay with $p$-nitrophenyl phosphate showed that clones pPB16, pPB17 and pPB18 exhibited much higher alkaline phosphatase activity than the other three clones, pPB27, pPB71 and pPB83. These results were consistent with the phenotypic analysis of the nested deletion clones with X-P (Fig. 2).

\section{Primer extension analysis to localise the start site of toxin B transcript}

The transcriptional initiation site of the toxin B mRNA was identified by primer extension analysis with the 5'end-labelled primer, PriExt, and total RNA extracted from clone $\mathrm{pPB}$. Two product bands were observed (Fig. 3), indicating that the 5 '-end of the toxin B mRNA was produced by two different promoters. Control experiments with either the RNA extracted from cells carrying the parental pQF110 vector, or adding RNAase prior to primer extension analysis did not show any product (Fig. 3). Therefore, the primer extension initiated from the mRNA encoded by the cloned DNA fragment. The longer transcript was mapped to an adenine residue which was $15 \mathrm{bp}$ upstream of the presumed toxin B start codon [10] (Fig. 4), and the shorter transcript started at a guanine residue 9 bp upstream of the toxin B start codon [10], 


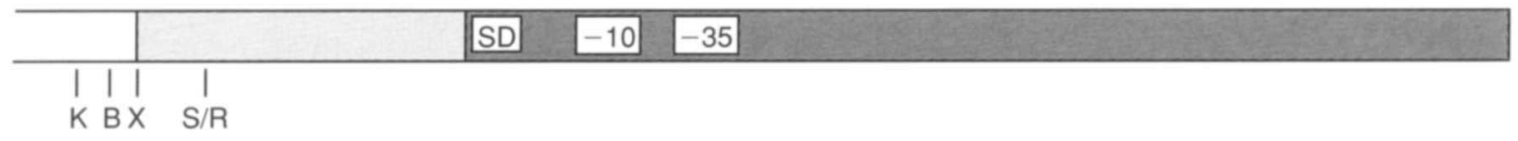

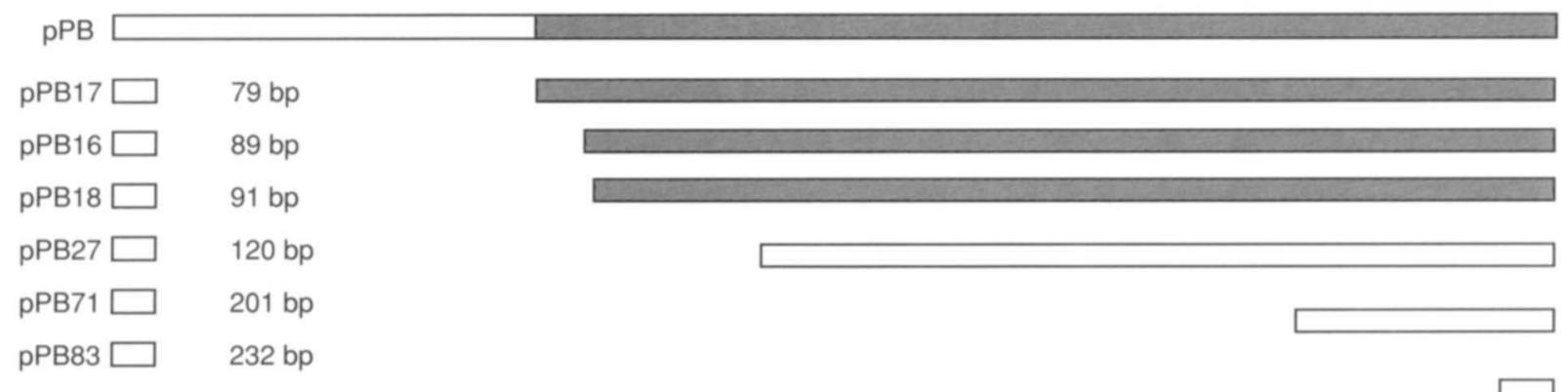

Fig. 2. Nested deletion analysis of clone pPB. The six deletion clones are shown with the amount of deletion measured from the KpnI site to the last nucleotide removed by exoIII. The relative positions of the putative Shine-Dalgarno (SD) sequence and the putative promoter region (the -35 and -10 ) are indicated. The blue and white phenotypes of the deletion clones are shown as $\mathbf{n}$, or $\square$, respectively. $\square$, represents the region of the cloned insert DNA containing $54 \mathrm{bp}$ of the $5^{\prime}$-end of the structural toxin B gene, beginning from the originally proposed initiation codon [10], and $8 \mathrm{bp}$ of the flanking pIBI25 vector sequence, as described in Fig. 1. Restriction enzymes are: B, Bam HI; K, KpnI; X, Xba I; $\mathbf{S} / \mathbf{R}$, junctional region between $S m a \mathrm{I}$ and $R s a \mathrm{I}$ sites.

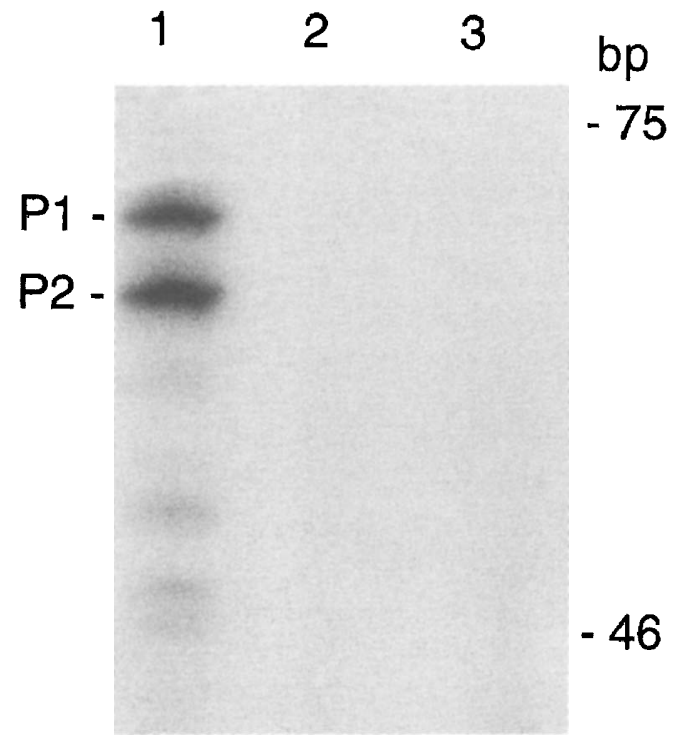

Fig. 3. Primer extension analysis of clone pPB. This was performed as described in Materials and methods and the two products, $\mathrm{P} 1$ and $\mathrm{P} 2$, were analysed on a denaturing polyacrylamide $9 \%$ gel. Lane 1 , RNA from clone $\mathrm{pPB} ; \mathbf{2}$, RNA from clone $p Q F 110 ; 3$, RNA from clone $p P B$, but treated with RNAase before primer extension. The numbers to the right indicate the positions of the relevant DNA size marker generated by digesting pIBI 25 plasmid with Sau3A.

which was also the last base of the 3 '-end of the putative Shine-Dalgarno sequence (Fig. 4).

\section{Discussion}

This study aimed to determine the location of the promoter for the toxin $\mathrm{B}$ gene of $C$. difficile, a clinically relevant organism whose toxins are believed to be the principal virulence factors in the enteric disease, pseudomembranous colitis. The study is necessarily done with $E$. coli, as $C$. difficile has not yet been successfully transformed with exogenous DNA. Based on the analysis of clone pPB (Fig. 1), promoter activity was found within the 400-bp DNA fragment upstream from the putative start codon of the toxin B gene. However, it is noted that the authentic initiation codon of the toxin B gene is not yet known, whether it is expressed in $E$. coli or $C$. difficile. Subsequent deletions of clone $\mathrm{pPB}$, followed by sequence analyses, also showed that if $>38 \mathrm{bp}$ upstream of the presumed toxin B gene initiation codon are deleted, promoter activity would be lost, yet it would not be affected if only $11 \mathrm{bp}$ of DNA are deleted (Fig. 2). This indicates that an essential part of the promoter occurs within the $11-38$-bp region upstream of the presumed start codon of the toxin B gene.

Also, as noted in Table 1, clone pPB exhibits 4.2-9.4fold less promoter activity than three of the deletion clones (pPB16, pPB17 and pPB18), as measured by the $p$-nitrophenyl phosphate assay. A possible explanation for this phenomenon is the presence of an inhibitory factor acting either at the transcriptional or translational levels to reduce the amount of the alkaline phosphatase activity being synthesised. It is not known why the alkaline phosphatase activity of clone pPB16 is lower than that of clones pPB17 and pPB18, although this is a very reproducible phenomenon. We speculate that this may be related to a less optimal positioning of the Shine-Dalgarno sequence in clone pPB16 compared to these other two clones, thus possibly reducing the efficiency of translation of the alkaline phosphatase product of clone pPB16. Never- 


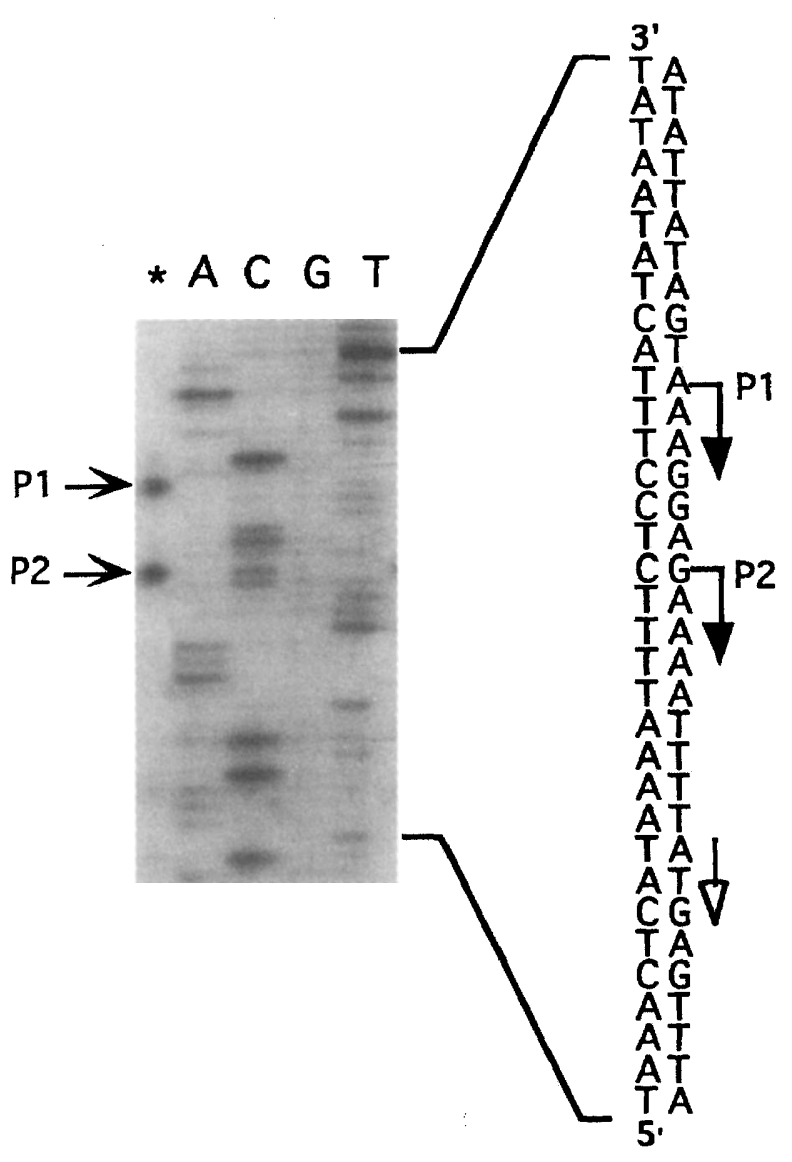

Fig. 4. Mapping of the 5 '-end of the toxin $B$ transcripts. RNA isolated from clone pPB was reverse transcribed into cDNA $\left({ }^{*}\right)$ with an 18-bp 5'-end-labelled oligonucleotide probe, and analysed on a denaturing polyacrylamide $5 \%$ gel. The sequence ladder (labeled A, C, G, T) shown is the antisense strand of DNA which was generated from the cloned DNA, using the same labelled oligonucleotide that was used for primer extension. The sequence around both transcriptional initiation sites is shown on the right. The $5^{\prime}$-ends of the two transcripts begin at $\mathrm{P} 1$ and $\mathrm{P} 2$. The originally assumed initiation codon [10], ATG, is also shown.

theless, these results still suggest that an essential part of a promoter is contained within the 27-bp DNA sequence missing in clone $\mathrm{pPB} 27$, as compared to clone pPB18 (Fig. 2), It has recently been reported [24] that a small opening reading frame immediately upstream of the toxin $B$ gene encodes a positive regulator for production of toxins $A$ and $B$. This protein might be expected to collaborate in vivo with the RNA polymerase of $C$. difficile to up-regulate production of both toxins, e.g., as a transcriptional activator or an alternative sigma factor.

The transcript mapping experiment (Fig. 3) showed two major bands of transcriptional initiation for the toxin $\mathrm{B}$ gene, when examining total RNA from clone pPB. Moreover, these two transcriptional initiation sites map in a location consistent with the promoter localisation results above. Taken together, these results suggest a two promoter model for transcriptional initiation of the toxin B gene, when it is expressed in this context in E. coli. Based on this model, the locations of both sets of -35 and -10 regions of the toxin $\mathrm{B}$ promoter can be inferred, assuming that these promoters share significant homology with the $E$. coli $\sigma^{70}$ consensus sequence [25]. In fact, two sets of promoter sequences, $\mathrm{P} 1$ and $\mathrm{P} 2$, can be postulated that are not only consistent with both transcripts, but are also closely related to promoter consensus sequences of gram-positive organisms [26] in general, and $C$. perfringens [27] in particular (Fig. 5). No comparable data are yet available for any genes of $C$. difficile. The P1 sequence, TATAAA $(\mathrm{N})_{20}$ TAAAAA, is proposed to constitute the -35 and -10 elements of the longer transcript, and the P2 sequence, TTAGCA(N) 17 TATAGT, is proposed for the promoter elements of the shorter transcripts (Fig. 6).

It is noteworthy that each transcript would begin only a few bases away from the proposed start codon of the toxin B gene [10] (Fig. 6). In fact, the longer transcripts starts only $2 \mathrm{bp}$ away from the putative Shine-Dalgarno sequence, and the start of the shorter transcript is even embedded within the same sequence (Fig. 6). Consequently, it is doubtful that toxin B mRNA would be translated from its presumed initiation site [10]. However, another potential inframe ATG initiation sequence is located $30 \mathrm{bp}$ downstream from the putative start codon of the toxin $B$ gene [10] (Fig. 6). This alternative putative initiation sequence is preceded by the sequence, $5^{\prime}$ AGAAA-3', which, although not a strong $E$. coli Shine-Dalgarno sequence, does exhibit perfect complementarity to the $3^{\prime}$-terminus of the $C$. perfringens 16s rRNA, 3'-UCUUUCCUCCACUAG-5' [28], and consequently is likely to be functional in $C$. difficile.

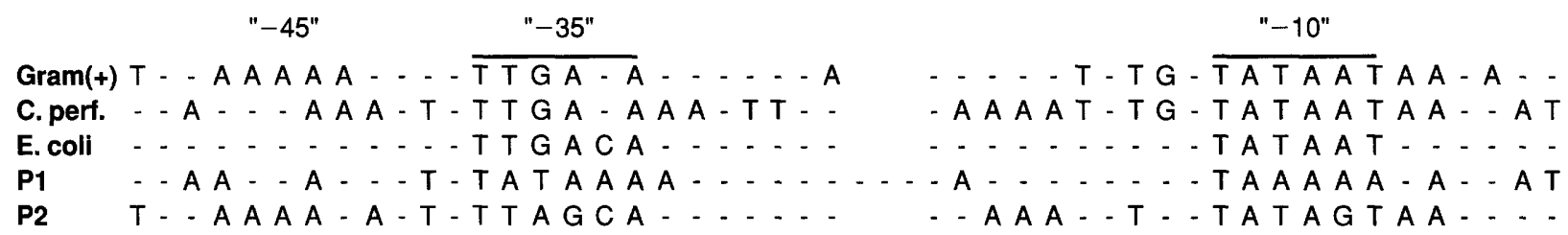

Fig. 5. Comparison of the putative promoter sequences of toxin $B$ with other prokaryotic promoter consensus sequences. The conserved promoter sequences (' -10 ' and ' -35 ' regions) of three systems, gram-positive $(\mathrm{Gram}(+)$, [26]), $C$. perfringens $(C$. perf., [27]) and $E$. coli [25] are shown. The ' -45 ' region is the postulated conserved sequence for gram-positive bacteria [26]. The proposed promoter sequences for both the longer and shorter transcripts are listed as $\mathrm{P} 1$ and $\mathrm{P} 2$, respectively. Spaces in the sequence correspond to alignment gaps. 


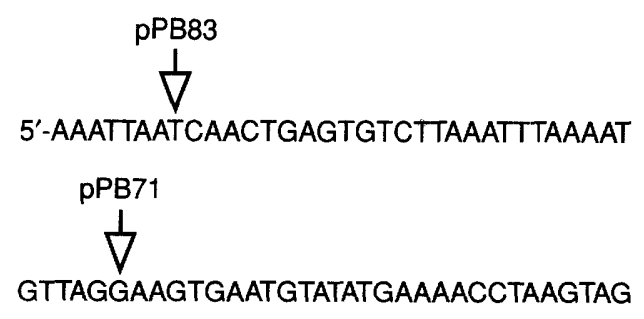

ATATTAGTATATTTTATAAATAGAAAGGAGGATA
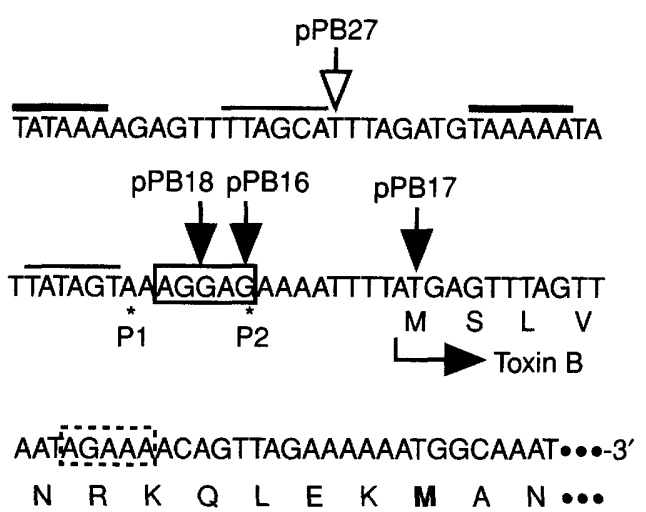

Fig. 6. Model of the putative toxin B dual promoter region expressed in $E$. coli. The two putative ribosomebinding sites (Shine-Dalgarno) are boxed, where the dashed box represents an alternative ribosome binding site suggested here for toxin B. The first nucleotide for each exolII deletion clone is indicated by an inverted arrow above the sequence with the name of the clone, where the open arrow, $\vec{\gamma}$, indicates no promoter activity and the filled arrow, $\downarrow$, indicates promoter activity. The asterisk by $\mathrm{P} 1$ or $\mathrm{P} 2$ designates the first base of the longer and shorter transcript, respectively, from primer extension analysis. Both sets of ' -35 ' and ' -10 ' putative promoter elements are overlined; the bold face type for the longer transcript, and the plain face type for the shorter transcript. The amino acids for toxin B are listed below the respective codons. The alternative initiation codon, $\mathbf{M}$, for toxin B suggested here is marked with bold face type.

However, it remains to be determined which initiation codon is used in vivo by $C$. difficile.

These two proposed promoters for toxin B not only fit the current models of $E$. coli and gram-positive $[26,27]$ consensus promoter sequences, but they also find additional support from gram-positive organisms in the -45 region of the promoter (Fig. 5). Further support for this model comes from clone pPB27 (Fig. 6 ), which does not contain both proposed -10 regions of this double promoter, and therefore would not be expected to express the alkaline phosphatase gene, as is actually observed (Fig. 2). In addition, other deletion clones, which either contain all the essential promoter elements known for $E$. coli, or none, display an alkaline phosphatase activity (Fig. 2) consistent with this double promoter model (Fig. 6).

If both promoters are used in vivo for $C$. difficile, a sporulating gram-positive bacterium, their purpose remains to be determined. This may be related to unique features of the toxin $B$ gene and its function in $C$. difficile, and the complex regulation anticipated for such toxin genes, whose expression correlates with sporulation [29]. For example, Bacillus subtilis, a wellcharacterised, sporulating gram-positive organism, utilises various $\sigma$ factors with different promoter specificities during sporulation. One of its genes, spoVG, contains two closely overlapping promoters, whose transcription during the different developmental stages of sporulation is controlled by at least two different $\sigma$ factors of the RNA polymerase [30]. Therefore, the promoter activity of the toxin $\mathrm{B}$ gene in $\mathrm{C}$. difficile may be under similarly complex regulation, which is absent in E. coli. This may involve some unique $\sigma$ factors and perhaps other regulatory factors, thus offering very interesting opportunities for futher work.

We are grateful to Drs Y. Pham and R. Rolfe for their suggestions during the course of the experiments. This work was supported in part by NIH grant AI-23894.

\section{References}

1. Bartlett JG, Chang TW, Gurwith M, Gorbach SL, Onderdonk AB. Antibiotic-associated pseudomembranous colitis due to a toxin-producing clostridia. $N$ Engl J Med 1978; 298: 531-534.

2. Bartlett JG, Onderdonk $\mathrm{AB}$, Cisneros RL, Kasper DL. Clindamycin-associated colitis due to a toxin-producing species of Clostridium in hamsters. J Infect Dis 1977; 136: 701-705.

3. Larson HE, Price AB, Honour P, Borriello SP. Clostridium difficile and the aetiology of pseudomembranous colitis. Lancet 1978; 1: 1063-1066.

4. Lyerly D, Robert MD, Phelps C, Wilkins TD. Purification and properties of toxins $\mathrm{A}$ and $\mathrm{B}$ of Clostridium difficile. FEMS Microbiol Lett 1986; 33: 31-35.

5. Lyerly DM, Lockwood DE, Richardson SH, Wilkins TD Biological activities of toxins $\mathrm{A}$ and $\mathrm{B}$ of Clostridium difficile. Infect Immun 1982; 35: 1147-1150.

6. Sullivan NM, Pellett S, Wilkins TD. Purification and characterization of toxins $\mathrm{A}$ and $\mathrm{B}$ of Clostridum difficile. Infect Immun 1982; 35: 1032-1040.

7. Taylor NS, Thorne GM, Bartlett JG. Comparison of two toxins produced by Clostridium difficile. Infect Immun 1981; 34: 1036-1043.

8. Lyerly DM, Sullivan NM, Wilkins TD. Enzyme-linked immunosorbent assay for Clostridium difficile toxin A. J Clin Microbiol 1983; 17: 72-78.

9. Laughon BE, Viscidi RP, Gdovin SL, Yolken RH, Bartlett JG. Enzyme immunoassays for detection of Clostridium difficile toxins $\mathrm{A}$ and B in fecal specimens. $J$ Infect Dis 1984; 149: $781-788$.

10. Barroso LA, Wang S-Z, Phelps CJ, Johnson JL, Wilkins TD. Nucleotide sequence of Clostridium difficile toxin B gene. Nucleic Acids Res 1990; 18: 4004.

11. Dove $\mathrm{CH}$, Wang SZ, Price SB et al. Molecular characterization of the Clostridium difficile toxin A gene. Infect Immun 1990; 58: $480-488$.

12. Sauerborn $M$, von Eichel-Streiber C. Nucleotide sequence of Clostridium difficile toxin A. Nucleic Acids Res 1990; 18: 1629-1630.

13. Dailey DC, Schloemer RH. Identification and characterization of a Clostridium difficile promoter element that is functional in Escherichia coli. Gene 1988; 70: 343-350.

14. Young M, Minton NP, Staudenbauer WL. Recent advances in the genetics of clostridia. FEMS Microbiol Rev 1989; 63: $301-326$.

15. Ronald SL, Kropinski AM, Farinha MA. Construction of broad-host-range vectors for the selection of divergent promoters. Gene 1990; 90: 145-148. 
16. Miller JH. Experiments in molecular genetics. Cold Spring Harbor, NY, Cold Spring Harbor Laboratory 1972.

17. Holmes DS, Quigley M. A rapid boiling method for the preparation of bacterial plasmids. Anal Biochem 1981; 114: $193-197$.

18. Sambrook J, Fritsch EF, Maniatis T. Molecular cloning: laboratory manual, 2nd edn. Cold Spring Harbor, NY, Cold Spring Harbor Laboratory 1989.

19. Sanger F, Nicklen S, Coulson AR. DNA sequencing with chain-terminating inhibitors. Proc Natl Acad Sci USA 1977; 74: $5463-5467$.

20. Grunstein M, Hogness DS. Colony hybridization: a method for the isolation of cloned DNAs that contain a specific gene. Proc Natl Acad Sci USA 1975; 72: 3961-3965.

21. Manoil C, Beckwith J. Tn phoA: a transposon probe for protein export signals. Proc Natl Acad Sci USA 1985; 82: 8129-8133.

22. Reddy KJ, Gilman M. Preparation of bacterial RNA. In: Ausubel FM, Brent R, Kingston RE et al. (eds) Current protocols in molecular biology. New York, Greene Publishing Associates and Wiley-Interscience. 1991: 4.4.1-4.4.7.

23. Triezenberg SJ. Primer extension. In: Ausubel FM, Brent R, Kingston RE et al. (eds) Current protocols in molecular biology. New York, Greene Publishing Associates and WileyInterscience. 1991: 4.8.1-4.8.5.

24. Moncrief JS, Barroso LA, Wilkins TD. Positive regulation of Clostridium difficile toxins. Infect Immun 1997; 65: 1105-1108.

25. McClure WR. Mechanism and control of transcription initiation in prokaryotes. Annu Rev Biochem 1985; 54: 171-204.

26. Graves MC, Rabinowitz JC. In vivo and in vitro transcription of the Clostridium pasteurianum ferredoxin gene. $J$ Biol Chem 1986; 261: 11409-11415.

27. Rood JI, Cole ST. Molecular genetics and pathogenesis of Clostridium perfringens. Microbiol Rev 1991; 55: 621-648.

28. Garnier T, Canard B, Cole ST. Cloning, mapping, and molecular characterization of the rRNA operons of Clostridium perfringens. $J$ Bacteriol 1991; 173: 5431-5438.

29. Kamiya S, Ogura H, Meng XQ, Nakamura S. Correlation between cytotoxin production and sporulation in Clostridium difficile. J Med Microbiol 1992; 37: 206-210.

30. Johnson WC, Moran CP, Losick R. Two RNA polymerase sigma factors from Bacillus subtilis discriminate between overlapping promoters for a developmentally regulated gene. Nature 1983; 302: 800-804. 